REFLEKSI HUKUM

Jurnal Ilmu Hukum
p-ISSN 2541-4984 | e-ISSN 2541-5417

Volume 3 Nomor 1, Oktober 2018, Halaman 97-114

DOI: https://doi.org/10.24246/jrh.2018.v3.i1.p97-114

Open access at: http://ejournal.uksw.edu/refleksihukum

Penerbit: Fakultas Hukum Universitas Kristen Satya Wacana

\title{
ASPEK HUKUM PERKAWINAN ANTAR AGAMA DAN PROBLEMATIKA YURIDISNYA
}

\author{
Tengku Erwinsyahbana \\ Fakultas Hukum Universitas Muhammadiyah Sumatera Utara \\ Korespondensi: tengkuerwins@umsu.ac.id
}

\begin{abstract}
Abstrak
Perkawinan antar agama diasumsikan akan terus terjadi sebagai akibat interaksi sosial di antara seluruh warga negara Indonesia yang pluralis agama, dan hal ini masih menimbulkan permasalahan yuridis yang terkait dengan pencatatan perkawinan tersebut, karena walaupun perkawinan telah berlangsung, KUA atau KCS dapat menolak untuk mencatatkan atau menolak untuk mengeluarkan akta perkawinannya.Perkawinan antar agama yang tidak dicatat akan menyebabkan status hukum pihak-pihak dalam perkawinan menjadi tidak pasti, dan perkawinan tersebut akan menimbukan problematika yuridis lainnya, yaitu: (1) hilangnya kewajiban ayah untuk mengasuh, mendidik, memelihara ataupun menafkahi anak yang lahir dari perkawinan; (2) ketidakpastian hukum terhadap kedudukan istri dalam perkawinan, sehingga istri dapat saja kehilangan hak-haknya dalam rumah tangga; (3) harta yang diperoleh selama dalam perkawinan dianggap tidak ada, dan ketika terjadi perceraian, masing-masing pihak tidak dapat saling menuntut untuk pembagian harta bersama; dan (4) anak yang lahir dari perkawinan itu dianggap sebagai anak yang tidak sah.
\end{abstract}

\section{Kata Kunci: Agama; Pencatatan; Perkawinan.}

\begin{abstract}
An interfaith marriage is assumed to be happened continually as a result of social interaction among all religious Indonesian pluralist citizens. Meanwhile, juridical problems related to marriage registration keep arising since KUA or KCS may refuse to issue marriage certificate. The unregistered interfaith marriage may affect the uncertainty of the legal status of the parties in the marriage and may create legal problems such as, (1) the loss of father's duty to take care, educate, and maintain or provide the children who are born in the marriage; (2) the uncertain legal status about the wife's position in the marriage which causes the wife may lose her rights in marriage; (3) the loss of the treasure that is obtained in the marriage and possibility to claim the treasure share when divorce occurs; (4) the legal status of the children who are born in the marriage will be assumed as illegitimate children.
\end{abstract}

Keywords: Religion; Registration; Marriage. 


\section{PENDAHULUAN}

Indonesia merupakan negara dengan masyarakat yang pluralistik dengan beragam suku dan agama, yang tercermin dari semboyan bangsa Indonesia yaitu: "Bhinneka Tunggal Ika". Dalam kondisi keberagaman seperti ini, akan terjadi interaksi sosial di antara kelompok-kelompok masyarakat yang berbeda yang dapat berlanjut pada hubungan perkawinan, dan termasuk perkawinan antar agama.

Undang-Undang Nomor 1 Tahun 1974 tentang Perkawinan (UU Perkawinan) mengakui bahwa sahnya perkawinan dilangsungkan berdasarkan agama dan kepercayaan yang sama dari dua orang yang berlainan jenis, tetapi dalam masyarakat yang pluralistik seperti di Indonesia, dapat terjadi perkawinan di antara dua orang pemeluk agama yang berbeda. Pasangan yang melaksanakan perkawinan antar agama, menempuh berbagai upaya untuk mendapatkan pengakuan negara, antara lain dengan meminta penetapan pengadilan, perpindahan agama sementara, melaksanakan perkawinan di luar negeri atau melaksanakan akad perkawinan dua kali (pertama menurut agama calon suami dan kedua menurut agama calon istri atau sebaliknya).

Ada beberapa contoh kasus perkawinan antar agama yang pernah diteliti oleh Siti Musdah Mulia, yaitu: ${ }^{1}$

1. Pasangan Wawan Wiratma (agama Khonghucu) dan Purnamawati Sugianto alias Ahong (agama Kristen), yang melangsungkan perkawinan antar agama pada tanggal 30 September 2001 di
Lithang Majelis Agama Khonghucu Indonesia (MAKIN) Jawa Barat.

2. Pasangan Wardah Hafidz (agama Islam) dan Wiladi (agama Khatolik), yang melangsungkan perkawinan antar agama di Jakarta, tetapi administrasi perkawinannya dilengkapi di Kantor Urusan Agama (KUA) Jombang Jawa Timur, karena pada waktu itu ayah Wardah adalah Kepala KUA.

3. Pasangan Lia Marpaung (agama Kristen) dan Adi Abidin (agama Islam), yang melangsungkan perkawinan antar agama pada tanggal 7 Januari 2005, di Wahid Institute Jakarta secara ajaran Islam dan pada tanggal 11 Januari 2005 di GKJ Sidomukti Salatiga secara ajaran Kristen.

4. Pasangan Agus Fardi (agama Islam) dan Enggar Nuryati (agama Khatolik), yang melangsungkan perkawinan antar agama pada tanggal 18 April 2004, di Gereja Santo Yusuf Mertoyudan Magelang Jawa Tengah.

5. Pasangan Ahmad Nurcholis (agama Islam) dan Ang Mei Yong (agama Khongucu), yang melangsungkan perkawinan antar agama pada tanggal 3 Juni 2003, di Pusat Studi Islam Paramadina Jakarta Selatan secara ajaran Islam dan di Lithang Matakin Sunter Jakarta Utara secara ajaran Khonghucu.

6. Pasangan Wandy Nicodemus Tuturong alias Binyo (agama Kristen) dan Farahdiba (agama Islam), yang melangsungkan perkawinan antar agama pada tanggal 9 Mei 1998, di rumah kediaman orang tua Farahdiba di Bandung secara ajaran Islam dan di Gereja GPIB Sumber 
Kasih Lebak Bulus Jakarta Selatan secara ajaran Kristen.

7. Pasangan Arum (agama Khatolik) dan Permadi (agama Islam), yang melangsungkan perkawinan antar agama pada tahun 2002 di Gereja Khatolik Santo Paulus Depok secara ajaran Khatolik dan di Mesjid Universitas Indonesia Depok secara ajaran Islam.

8. Pasangan Dewi (Penghayat) dan Okky (agama Khatolik), yang melangsungkan perkawinan antar agama pada tanggal 3 Maret 2002.

9. Pasangan Yani Mulyani (Penghayat) dan Tio Nugroho (agama Islam), yang melangsungkan perkawinan antar agama pada bulan Juli 2005 secara adat Sunda (tidak secara agama).

10. Pasangan Indra (agama Islam) dan Patsy (agama Khatolik), yang melangsungkan perkawinan antar agama pada tahun 2002 dua kali, yaitu secara ajaran Islam yang difasilitasi oleh Yayasan Paramadina dan secara ajaran Khatolik di Gereja.

Beberapa kasus di atas hanya sebagian kecil dari contoh praktik perkawinan antar agama, karena banyak warga negara Indonesia yang menunggu (antrian) untuk melangsungkan perkawinan antar agama di negara lain.

Perkawinan antar agama terjadi sebagai realitas sosial yang tidak dapat dihindari, padahal dalam UU Perkawinan, tidak diatur secara tegas, dan diasumsikan akan terus terjadi sebagai akibat interaksi sosial di antara seluruh warga negara Indonesia yang pluralis agama. Permasalahan dalam perkawinan antar agama muncul jika terjadi penolakan pencatatan terhadap perkawinan tersebut, karena walaupun pasangan suami istri telah melangsungkan perkawinan menurut ajaran agama, KUA atau Kantor Catatan Sipil (KCS) dapat menolak untuk mencatatkan atau menolak mengeluarkan akta perkawinannya. Kondisi ini akan menimbulkan ketidakpastian hukum terhadap hak-hak istri dan anak yang lahir dari perkawinan orang tua yang berbeda agama.

Tidak dicatatnya suatu perkawinan karena adanya penolakan pencatatan dari lembaga yang berwenang (KUA dan KCS) akibat perkawinan antar agama, tentunya menimbulkan konsekuensi bahwa perkawinan tersebut tidak mengikat, sehingga dapat dipastikan bahwa yang mengalami kerugian terutama adalah isteri atau dari pihak keluarga isteri serta anak-anak (keturunannya). ${ }^{2}$ Kondisi ini tidak dapat dibiarkan, karena menimbulkan rasa ketidakadilan dalam perkawinan, padahal salah satu tujuan hukum adalah mewujudkan keadilan, tetapi fakta yang terjadi justru masih ada penolakan pencatatan yang dilakukan oleh lembaga yang berwenang (KUA ataupun KCS) dengan alasan bahwa perkawinan antar agama tidak sah berdasarkan agama dan UU Perkawinan, padahal jika mencermati UU Nomor 23 Tahun 2006 tentang Administrasi Kependudukan yang kemudian diubah dengan UU No. 24 Tahun 2013 tentang Perubahan Atas UU No. 23 Tahun 2006 tentang Administrasi Kependudukan, maka pencatatan perkawinan merupakan

2 Menurut Rachmadi Usman dikatakan bahwa tidak dicatatnya perkawinan, maka perkawinan yang dilangsungkan para pihak tidak mempunyai kekuatan hukum dan bukti sebagai suatu perkawinan. Lihat Rachmadi Usman, 'Makna Pencatatan Perkawinan dalam Peraturan Perundangundangan Perkawinan di Indonesia' (2017) 14 Jurnal Legislasi Indonesia 255, 256. 
[Vol. 3, No. 1, 2018]

kewajiban dan sekaligus sebagai hak setiap penduduk di Indonesia. Dapat diasumsikan bahwa terdapat ketidaksingkronan antara UU Perkawinan dengan UU Adminduk, karena pada satu sisi UU Perkawinan tidak mengatur secara tegas tentang boleh atau tidaknya perkawinan antar agama, sedangkan pada sisi lain ketika peristiwa perkawinan terjadi (termasuk pula perkawinan antar agama), maka setiap penduduk wajib melaporkannya kepada lembaga yang berwenang (KUA ataupun KCS).

Realitas perkawinan antar agama ini menarik untuk diteliti dan dianalisis, mendeskripsikan problematika yuridis perkawinan antar agama yang dikaitkan dengan fungsi pencatatan perkawinan, yang jenisnya merupakan penelitian hukum normatif, ${ }^{3}$ dengan pendekatan perundang-undangan. ${ }^{4}$

Penelitian ini hanya untuk menganalisis data sekunder, maka metode pengumpulan data yang digunakan yaitu metode studi dokumen, dan berhubung penelitian ini merupakan penelitian hukum normatif, maka analisis data yang digunakan adalah analisis kualitatif atau lebih tepat disebut analisis yuridis kualitatif. 5

\section{PEMBAHASAN}

\section{Pencatatan Perkawinan Antar Agama}

Perkawinan sah secara hukum apabila memenuhi syarat-syarat materil dan syarat-syarat formil. Di Indonesia, syarat sahnya perkawinan di atur dalam UU Perkawinan, yang berdasarkan Pasal 2, maka perkawinan sah secara hukum apabila dilakukan menurut hukum agama dan kepercayaan dari masing-masing pihak yang akan menikah dan dicatat menurut peraturan perundang-undangan yang berlaku. Syarat materil dari perkawinan yang dimaksud dalam ketentuan ini adalah adalah syarat sah menurut agama masing-masing pihak dan jika kemudian perkawinan akan dilakukan oleh pasangan yang berbeda agama, maka kembali merujuk pada hukum agama masingmasing pihak. Syarat formil perkawinan terkait dengan masalah pencatatan perkawinan sebagaimana dimaksud dalam UU Perkawinan, serta peraturan pelaksanaannya.

Ada 2 (dua) lembaga terkait yang bertugas untuk melaksanakan pencatatan perkawinan, yaitu KUA yang bertugas untuk mencatatkan perkawinan pasangan suami istri yang beragama Islam dan KCS yang bertugas untuk mencatatkan perkawinan yang beragama selain Islam, dan hal ini dapat menimbulkan permasalahan,

3 Penelitian hukum normatif adalah penelitian terhadap bahan kepustakaan (data sekunder) yang relevan dengan permasalahan yang akan dianalisis, baik berupa bahan hukum primer, bahan hukum sekunder maupun bahan hukum tertier. Lihat Soerjono Soekanto dan Sri Mamudji, Penelitian Hukum Normatif, Suatu Tinjauan Singkat (RadaGrafindo Persada 2003) 14.

4 Penelitian hukum normatif dengan pendekatan perundang-undangan, berarti fokus penelitiannya adalah terhadap berbagai aturan hukum sebagai tema sentralnya. Lihat Johny Ibrahim, Teori dan Metodologi Penelitian Hukum Normatif (Bayumedia Publishing 2006) 302.

5 Disebut analisis yuridis kualitatif karena yang dianalisis adalah informasi yang didapat dari peraturan perundang-undang, serta tulisan-tulisan ilmiah dalam bidang hukum (yuridis). Tengku Erwinsyahbana, 'Pertanggungjawaban Yuridis Direksi Terhadap Risiko Kerugian Keuangan Daerah pada Badan Usaha Milik Daerah' (2017) 2 Jurnal De Lega Lata 188-189. 
karena UU Perkawinan hanya melindungi pencatatan perkawinan penganut 6 (enam) agama resmi negara dan penganut kepercayaan, padahal tidak semua warga negara di Indonesia digolongkan atau dikelompokan ke dalam 6 (enam) penganut agama negara dan penganut kepercayaan. ${ }^{6}$ Selain itu, termasuk pula masalah pencatatan bagi orang yang melangsungkan perkawinan antar agama.

UU Perkawinan menyerahkan keabsahan perkawinan pada hukum agama, sehingga ketika hukum agama memperkenankan terjadinya perkawinan antar agama, maka hal tersebut tidak akan menjadi masalah. Dalam praktik ada juga lembaga keagamaan tertentu yang mau mengesahkan perkawinan antar agama dengan persyaratan-persyaratan, izin atau dispensasi, dan jika hal ini terjadi, maka KCS seharusnya mencatatkan perkawinan ini, tetapi kenyataannya bahwa KCS selalu menolak melaksanakan pencatatan perkawinan antar agama yang telah dilangsungkan. Penolakan yang dilakukan oleh KCS cukup beralasan dilihat secara yuridis, karena UU Perkawinan tidak ada mengatur perkawinan antar agama, yang diatur hanyalah perkawinan campuran dalam arti perkawinan antara dua orang yang di Indonesia tunduk pada hukum yang berlainan (perbedaan kewarganegaraan) yang satu pihak berkewarganegaraan asing dan pihak lainnya berkewarganegaraan Indonesia.

Sebelum berlakunya UU Perkawinan, terdapat peraturan yang mengatur tentang perkawinan antar agama, yaitu GHR dan HOCI, sedangkan berdasarkan kedua peraturan ini penyelenggaraan perkawinan antar agama tidak menjadi problematik dan pencatatannya dilakukan dalam daftar perkawinan campuran pada Kantor Catatan Sipil. 7 Problematika yuridis terjadi justru setelah berlakunya UU Perkawinan, yang tidak mengatur perkawinan antar agama secara tegas.

Setelah dikeluarkannya Kepres No. 12 Tahun 1983 tentang Penataan dan Peningkatan Pembinaan dan Penyelenggaraan Catatan Sipil, maka berkenaan dengan pencatatan perkawinan yang berdasarkan Pasal 1 ayat (2) disebutkan bahwa KCS diberi kewenangan pencatatan dan penerbitan kutipan akta-akta bagi mereka yang bukan beragama Islam. Tidak adanya pengaturan perkawinan antar agama secara tegas dan eksplisit dalam UU Perkawinan termasuk pencatatannya mengakibatkan terjadinya ketidakpastian hukum, sehingga jika benar-benar terjadi kasus seperti itu, maka status hukum perkawinan tersebut menjadi tidak jelas dan dapat memaksa orang untuk berpindah agama atau mengikuti agama salah satu pihak untuk menghindari permasalahan yuridis.

Ketidakpastian hukum itu juga terjadi dalam bentuk keanekaragaman pelaksanaan perkawinan antar agama, seperti adanya kasus mempelai yang melaksanakan perkawinan dua kali, pertama menurut hukum agama suami dan kemudian menurut hukum agama istri. Begitu pula berkenaan dengan pencatatan perkawinan antar agama yang kewenangan KCS sebagai institusi yang melangsungkan dan

6 Ceprudin, 'Perlindungan Hukum terhadap Perkawinan Penganut Sedulur Sikep di Kabupaten Kudus' (2016) 1 Refleksi Hukum: Jurnal Ilmu Hukum 81, 84.

7 Sunaryati Hartono, Politik Hukum Menuju Satu Sistem Hukum Nasional (Alumni 1991) 147. 
mencatat perkawinan itu belum jelas. Pasal 20 UU Perkawinan, secara implisit memperbolehkan Pegawai Pencatat Perkawinan melangsungkan dan mencatat perkawinan antar agama atau berdasarkan Pasal 21, maka prosesnya harus melalui prosedur Pengadilan Negeri terlebih dahulu untuk memperoleh keputusan yang mengikat.

Ketentuan lain yang perlu dicermati dalam Pasal 35 huruf a UU Adminduk, yang menentukan bahwa pencatatan perkawinan sebagaimana dimaksud dalam Pasal 34 berlaku pula bagi perkawinan yang ditetapkan oleh pengadilan. Dalam Penjelasan Pasal 35 huruf a disebutkan bahwa yang dimaksud dengan perkawinan yang ditetapkan oleh pengadilan adalah perkawinan yang dilakukan antar umat yang berbeda agama, sedangkan Pasal 34 ayat (1) dan (2) menentukan bahwa: (1) perkawinan yang sah berdasarkan ketentuan perundang-undangan wajib dilaporkan oleh penduduk kepada instansi pelaksana di tempat terjadinya perkawinan paling lambat 60 (enam puluh) hari sejak tanggal perkawinan; dan (2) berdasarkan laporan sebagaimana yang dimaksud pada ayat (1), Pejabat Pencatatan Sipil mencatat pada Register Akta Perkawinan dan menerbitkan Kutipan Akta Perkawinan. Selanjutnya dalam penjelasan Pasal 34 ayat (1) dan (2), disebutkan bahwa: yang dimaksud dengan perkawinan adalah ikatan lahir batin antara seorang pria dan seorang wanita sebagai suami istri berdasarkan ketentuan perundang-undangan, dan penerbitan akta perkawinan bagi penduduk yang beragama Islam dilakukan oleh Departemen Agama. Berdasarkan Pasal 35 huruf a UU Adminduk, maka KCS sekarang memiliki kewenangan untuk mencatat perkawinan antar agama yang telah mendapatkan penetapan dari pengadilan, maka semestinya pasangan yang hendak melangsungkan perkawinan antar agama dapat mencatatkan perkawinannya di KCS setelah terlebih dahulu mengajukan permohonan penetapan kepada pengadilan.

Berlakunya UU Adminduk telah memperjelas status hukum lembaga catatan sipil di Indonesia, karena secara fungsional yang mempunyai kewenangan dan tanggung jawab penyelenggaraan catatan sipil berada di dalam lingkup, kewenangan dan tanggung jawab Kementrian Dalam Negeri, maka untuk penyelenggaraan pencatatan sipil di daerah merupakan tanggung jawab gubernur sebagai kepala pemerintah propinsi dan bupati/walikota sebagai kepala daerah pemerintah kabupaten/kota. Adapun kewajiban dan tanggung jawab penyelengaraan urusan pencatatan sipil yang dilakukan oleh gubernur mempunyai kewenangan yaitu: pemberian bimbingan, supervisi dan konsultasi pelaksanaan pendaftaran penduduk dan pencatatan sipil. Kewajiban dan tanggung jawab penyelenggaraan pencatatan sipil diselenggarakan pemerintah kabupaten/kota dilakukan oleh bupati/walikota dengan kewenangannya membentuk instansi pelaksana yang tugas dan fungsinya di bidang administrasi penduduk, sedangkan instansi pelaksana berdasarkan Pasal 8 ayat (1) UU Adminduk, berkewajiban untuk:

1. Mendaftar peristiwa kependudukan dan mencatat peristiwa penting;

2. Memberikan pelayanan yang sama dan profesional kepada setiap penduduk atas pelaporan peristiwa kependudukan dan peristiwa pen- 
ting;

3. Mencetak, menerbitkan, dan mendistribusikan dokumen kependudukan;

4. Mendokumentasikan hasil pendaftaran penduduk dan pencatatan sipil;

5. Menjamin kerahasiaan dan keamanan data atas peristiwa kependudukan dan peristiwa penting; dan

6. Melakukan verifikasi dan validasi data dan informasi yang disampaikan oleh penduduk dalam pelayanan pendaftaran penduduk dan pencatatan sipil.

Memperhatikan kewajiban lembaga catatan sipil sebagaimana tersebut dalam Pasal 8 ayat (1) UU Adminduk ini, maka sebenarnya tidak ada alasan bagi KCS untuk menolak permohonan pencatatan perkawinan antar agama yang jika perkawinan tersebut telah dilaksanakan dan disahkan oleh lembaga keagamaan (sudah sah menurut ajaran agama para pihak). Terlebih lagi bahwa KCS bukan merupakan lembaga yang mempunyai kewenangan untuk menentukan sah atau tidaknya suatu perkawinan, melainkan hanya sebagai lembaga yang mempunyai tugas dan kewajiban untuk mencatat setiap peristiwa penting yang terkait dengan kehidupan seseorang, dan peristiwa penting sebagaimana dimaksud dalam Pasal 1 angka 17 UU Adminduk adalah kejadian yang dialami oleh seseorang meliputi kelahiran, kematian, lahir mati, perkawinan, perceraian, pengakuan anak, pengesahan anak, pengangkatan anak, perubahan nama dan perubahan status kewarganegaraan.

UU Adminduk tidak ada mengatur secara khusus mengenai proses pencatatan perkawinan antar agama, sedangkan dalam Pasal 35 huruf a hanya disebutkan bahwa pencatatan perkawinan sebagaimana dimaksud oleh Pasal 34 UU ini juga berlaku bagi perkawinan yang ditetapkan oleh Pengadilan dan dalam penjelasan Pasal 35 huruf a yang dimaksud dengan perkawinan yang ditetapkan pengadilan adalah perkawinan yang dilakukan antar umat yang berbeda agama. Proses pencatatan perkawinan antar agama sama seperti perkawinan pada umumnya, bedanya bahwa pasangan perkawinan antar agama harus menyertakan penetapan pengadilan sebagai bagian persyaratan pencatatan perkawinan antar agama. Proses pencatatan perkawinan diatur lebih lanjut dalam Perpres No. 25 Tahun 2008 tentang Persyaratan dan Tata Cara Pendaftaran Penduduk dan Pencatatan Sipil, mulai Pasal 67 sampai dengan Pasal 69, yang menentukan sebagai berikut:

1. Pencatatan perkawinan dilakukan di Instansi Pelaksana atau UPTD Instansi Pelaksana tempat terjadinya perkawinan.

2. Pencatatan perkawinan dilakukan dengan memenuhi syarat berupa:

a. Surat keterangan telah terjadinya perkawinan dari pemuka agama/pendeta atau surat perkawinan Penghayat Kepercayaan yang ditanda tangani oleh Pemuka Penghayat Kepercayaan;

b. KTP suami dan istri;

c. Pas foto suami dan istri;

d. Kutipan Akta Kelahiran suami dan istri; serta

e. Paspor bagi suami atau istri orang asing.

3. Pencatatan perkawinan dilakukan dengan tata cara:

a. Pasangan suami dan istri mengisi formulir pencatatan perkawinan pada UPTD Instan- 
si Pelaksana atau pada Instansi Pelaksana dengan melampirkan persyaratan sebagaimana dimaksud pada angka 2;

b. Pejabat Pencatatan Sipil pada UPTD Instansi Pelaksana atau Instansi Pelaksana mencatat pada Register Akta Perkawinan dan menerbitkan Kutipan Akta Perkawinan;

c. Kutipan Akta Perkawinan sebagaimana dimaksud pada huruf b diberikan kepada masingmasing suami dan istri;

d. Suami atau istri berkewajiban melaporkan hasil pencatatan perkawinan kepada Instansi Pelaksana atau UPTD Instansi Pelaksana tempat domisilinya.

4. Data hasil pencatatan KUA Kecamatan atas peristiwa perkawinan, disampaikan kepada Instansi Pelaksana untuk direkam ke dalam database kependudukan.

5. Data hasil pencatatan KUA Kecamatan tidak dimaksudkan untuk penerbitan kutipan akta perkawinan.

6. Pencatatan perkawinan berdasarkan penetapan pengadilan dilakukan di Instansi Pelaksana atau UPTD Instansi Pelaksana.

7. Pencatatan perkawinan dilakukan dengan cara menunjukkan penetapan pengadilan.

Berdasarkan ketentuan yang terdapat dalam UU Adminduk dan berdasarkan PP No. 25 Tahun 2008, maka jika suatu perkawinan antar agama telah mendapat Penetapan Pengadilan, maka sudah semestinya KCS tidak perlu lagi mempersoalkan masalah pengesahan agama. KCS sesuai Pasal 35 huruf a UU Adminduk berwenang mencatatkan perkawinan antar agama tersebut. Proses pencatatannya sama dengan pencatatan per- kawinan pada umumnya dan kutipan akta perkawinan yang diterbitkan juga tidak berbeda dengan akta perkawinan pada umumnya.

Persoalan terkait dengan penetapan pengadilan terhadap perkawinan antar agama ini, semakin menimbulkan ketidakpastian hukum atas ketentuan yang terdapat dalam Pasal 2 ayat (1) UU Perkawinan, karena berdasarkan ketentuan ini disebutkan bahwa perkawinan adalah sah jika dilaksanakan menurut agama masingmasing pihak, sementara ada agama (seperti Islam dan Hindu) yang sama sekali tidak membolehkan perkawinan antar agama, tetapi mengingat Pasal 35 huruf a UU Adminduk, dapat saja perkawinan antar agama yang salah satu pihak beragama Islam atau Hindu diakui pelaksanaannya setelah mendapat penetapan pengadilan. Sebaliknya UU Perkawinan juga memberikan peluang untuk terjadinya perkawinan antar agama melalui penetapan pengadilan, karena berdasarkan Pasal 21 UU Perkawinan disebutkan apabila Pegawai Pencatat dalam hal ini KCS berpendapat bahwa perkawinan tidak dapat dilangsungkan dan dicatatkan karena melanggar UU Perkawinan, maka ia wajib mengeluarkan penolakan tertulis. Penolakan tertulis dapat digugat ke Pengadilan dan Pengadilan dapat memutuskan apakah penolakan itu memang tepat atau sebaliknya memutuskan bahwa perkawinan itu dapat dicatatkan.

UU Adminduk terkesan memberikan peluang bagi terjadinya perkawinan antar agama di Indonesia, tetapi perlu dicermati bahwa ketentuan yang terdapat pada Pasal 35 huruf a UU Adminduk hanya memberi kemungkinan pencatatan perkawinan antar agama di KCS jika Pengadilan telah memerintahkan demikian, berarti 
hanya pengadilan yang menentukan boleh atau tidak perkawinan dicatatkan oleh KCS. Hakim dalam hal ini memiliki wewenang untuk menilai keabsahan perkawinan antar agama, walaupun menurut Alesyanti (dkk), dikatakan bahwa "the problem of value is an abstract problem so difficult to express concretely; the occurrence of differences of opinion on the issue of value is difficult to avoid, especially coupled with the lack of public sensitivity to the value that is considered good" (masalah nilai adalah masalah abstrak, sehingga sulit untuk diungkapkan secara konkrit, terjadinya perbedaan pendapat tentang masalah nilai sulit dihindari, apalagi ditambah dengan kurangnya sensitifitas publik terhadap nilai yang dianggap baik). ${ }^{8}$

Hal yang perlu diperhatikan oleh seorang hakim dalam menilai keabsahan perkawinan antar agama adalah ketentuan yang terdapat dalam Pasal 2 ayat (1) UU Perkawinan, karena untuk menilai sah atau tidak sahnya perkawinan yang dilangsungkan harus tetap berpedoman pada ajaran (hukum) agama. Sesuatu perbuatan yang tidak boleh menurut hukum agama, maka semestinya tidak boleh pula menurut hukum negara, oleh sebab itu hakim pun tidak boleh memutuskan bahwa sesuatu perbuatan itu adalah sah jika menurut hukum agama dan hukum negara tidak dibolehkan. Atas dasar ini, penulis beranggapan bahwa terkait dengan perkawinan antar agama, maka bukan kewenangan hakim untuk menentukan perkawinan itu sah, melainkan hanya sebatas memerintahkan kepada KCS untuk men- catat perkawinan yang sudah berlangsung di hadapan lembaga atau pihak yang berwenang untuk mengawinkan. Dengan kata lain, bahwa perintah yang diberikan oleh Hakim (Pengadilan) kepada KCS hanya terbatas untuk memberikan pengakuan (legalisasi) terhadap perkawinan antar agama, jadi tidak untuk menentukan bahwa suatu perkawinan adalah sah menurut ajaran agama, dengan kata lain bahwa KCS hanya memiliki kewenangan untuk mencatatkan perkawinan antar agama atas perintah pengadilan atau KCS hanya berwenang mencatatkan bukan mengawinkan karena KCS bukan lembaga yang berfungsi mengawinkan.

Sehubungan dengan uraian di atas, jika suatu perkawinan antar agama telah mendapat Penetapan Pengadilan dan dicatatkan di KCS, maka perkawinan tersebut telah mempunyai status hukum yang sama seperti perkawinan pada umumnya menurut hukum negara, walaupun menurut hukum agama tidak demikian. Hal ini dilakukan semata-mata untuk melindungi kepentingan para pihak yang terikat perkawinan dalam pengertian yuridis, tetapi tidak dalam pengertian teologis. Pencatatan perkawinan menjadi penting fungsinya dalam perspektif hukum positif di Indonesia, yang pada akhirnya bertujuan untuk membedakan antara keturunan sah dan keturunan tidak sah. Keturunan sah didasarkan atas adanya perkawinan yang sah, dalam arti bahwa yang satu adalah keturunan yang lain berdasarkan kelahiran dalam atau sebagai akibat perkawinan yang sah, anak-anak yang

8 Alesyanti, Tengku Erwinsyahbana, and Fatimah Sari Siregar, 'Design of Sex Educational Material in Children as Early Anticipation of Pedophilia in Medan City and its Dissemination through Information and Communication Technology' (2018) 1114 Journal of Physics: Conference Series 1, 2. 
demikian disebut anak sah, sedangkan keturunan tidak sah adalah keturunan yang tidak didasarkan atas suatu perkawinan yang sah, atau dalam istilah lain disebut dengan anak luar kawin. 9

\section{Problematika Yuridis dalam Perkawinan Antar Agama Dikaitkan dengan Fungsi Pencatatan Perkawinan}

Ketidaktegasan UU Perkawinan dalam mengatur perkawinan antar agama menimbulkan ketidakjelasan status hukum perkawinan tersebut apakah sah atau tidak, sedangkan ketentuan yang terdapat UU Perkawinan yang dapat dihubungkan dengan perkawinan antar agama masih perlu penafsiran, sehingga kepastian hukum dalam konteks ini sulit diwujudkan. Seperti yang telah diuraikan di atas, bahwa salah satu permasalahan yang dihadapi oleh pasangan yang melangsungkan perkawinan antar agama adalah adanya penolakan dari pegawai pencatat perkawinan untuk mencatatkan perkawinan tersebut. Akhirnya dalam banyak kasus ditemui bahwa pasangan yang melangsungkan perkawinan antar agama ini tidak mempunyai bukti otentik (akta perkawinan) yang menunjukkan adalah benar perkawinan telah berlangsung. Akibat dari kondisi ini, dapat dipastikan bahwa yang akan mengalami kerugian adalah dari pihak istri dan anakyang lahir dari perkawinan tersebut.

Setiap orang umumnya menginginkan agar perkawinannya mendapat pengakuan secara yuridis, dan pengakuan dimaksud adalah melalui pencatatan perkawinan, sehingga peristiwa perkawinan tersebut menjadi jelas dan terang. serta memenuhi syarat pencatatan perkawinan, yang dibuktikan dengan akta pernikahan. Melalui pencatatan perkawinan, maka akan menimbulkan segala konsekuensi yuridis, baik bagi kedua pasangan suami istri, keturunan dan masyarakat sekitarnya, serta bagi semua pihak yang berkepentingan. Pencatatan perkawinan dilakukan pada dasarnya untuk memenuhi ketentuan Pasal 2 ayat (2) UU Perkawinan, yang menegaskan bahwa tiap-tiap perkawinan dicatat menurut peraturan perundang-undangan yang berlaku. Peraturan perundang-undangan yang dimaksud adalah PP No. 9 Tahun 1975 tentang Pelaksanaan UU No. 1 Tahun 1974 tentang Perkawinan. Terhadap perkawinan yang telah memenuhi syarat-syarat materil dalam perkawinan biasanya tidak menghadapi banyak hambatan dalam upaya pencatatan perkawinannya, tetapi bagi pasangan yang berbeda agama yang dianggap belum memenuhi syaratsyarat materil perkawinan, selalu ditolak oleh lembaga pencatat perkawinan ketika akan mencatatkan perkawinannya guna mendapatkan akta perkawinan. Bagi pihak-pihak yang mendapat penolakan dari KCS atau KUA, dan selanjutnya memintakan penetapan kepada pengadilan, maka akan dapat memperoleh akta perkawinan, tetapi bagi pihak-pihak yang tidak melakukan upaya hukum untuk mendapatkan akta perkawinannya, maka dapat dipastikan bahwa terhadap perkawinan tersebut akan menim-

\footnotetext{
9 Tengku Erwinsyahbana dan Harmita, 'Kekuatan Hukum Surat Keterangan Ahli Waris bagi Anak
} Luar Kawin dari Perkawinan Tidak Tercatat' (2017) 8 Jurnal Hukum Novelty 269, 271. 
bulkan problematika yuridis lebih lanjut, yaitu:

1. Hilangnya kewajiban ayah untuk mengasuh, mendidik, memelihara ataupun menafkahi anak yang lahir dari perkawinan itu, karena secara yuridis ayah dan anak tidak mempunyai hubungan yang bersifat keperdataan, dan konsekuensi selanjutnya bahwa ketika salah satu pihak lebih dahulu meninggal dunia, maka tidak hubungan saling mewarisi dari harta yang ditinggalkan.

2. Kedudukan istri dalam perkawinan, bahwa jika perkawinan tidak dicatatkan, maka terhadap perkawinan tersebut dianggap tidak pernah ada perkawinan dilangsungkan. Konsekuensi yuridis dari keadaan ini menimbulkan ketidakpastian hukum terhadap kedudukan istri dalam perkawinan, sehingga istri dapat saja kehilangan hak-haknya dalam rumah tangga, misalnya hak atas nafkah dari suami ataupun hak untuk mewarisi harta peninggalan suaminya jika suami lebih dahulu meninggal dunia.

3. Masalah harta benda perkawinan, karena bagi perkawinan yang tidak dicatatkan, berarti secara yuridis dianggap tidak pernah terjadi, maka harta benda yang diperoleh selama dalam perkawinan (harta bersama) tentu dianggap tidak ada, dan ketika terjadi perceraian, masing-masing pihak tidak dapat saling menuntut untuk diadakannya pembagian terhadap harta bersama.
4. Terhadap status anak, bahwa dengan tidak tercatatnya perkawinan, maka anak yang lahir dari perkawinan itu dianggap sebagai anak yang tidak sah, dengan demikian hanya mempunyai hubungan keperdataan dengan ibunya dan keluarga-keluarga ibunya. Berdasarkan Pasal 42 UU Perkawinan, ditentukan bahwa anak yang sah adalah anak yang dilahirkan dalam atau sebagai akibat perkawinan yang sah, dengan demikian dapat ditafsirkan bahwa anak tidak sah adalah anak yang lahir dari perkawinan orang tuanya yang tidak sah. Konsekuensi selanjutnya dari keadaan ini bahwa anak yang lahir dari perkawinan tersebut dianggap sebagai anak yang tidak mempunyai ayah secara yuridis. ${ }^{10}$

Beberapa problematika yuridis sebagaimana tersebut di atas, terjadi karena tidak ada alat bukti (akta perkawinan) yang menunjukkan bahwa pada satu waktu tertentu adalah benar telah terjadi peristiwa perkawinan antara seorang pria dengan seorang wanita. Akibatnya, perkawinan seperti ini hanya dianggap pernah terjadi secara sosiologis, dalam pengertian bahwa masyarakat yang menyaksikan perkawinan tersebut mengakui bahwa seseorang adalah benar sebagai pasangan suami istri, tetapi jika dilihat dari aspek yuridis, maka perkawinan tersebut dianggap tidak mempunyai kekuatan hukum. Untuk dapat membuktikan bahwa perkawinan telah terjadi, maka berdasarkan UU perkawinan dan PP No. 9 Tahun 1975, maka perkawinan

10 Setelah keluarnya Putusan Mahkamah Konstitusi Nomor 46/PUU-VIII/2010, maka anak yang dilahirkan di luar perkawinan, tetap mempunyai hubungan perdata dengan laki-laki sebagai ayahnya yang dapat dibuktikan berdasarkan ilmu pengetahuan dan teknologi dan/atau alat bukti lain menurut hukum mempunyai hubungan darah, termasuk hubungan perdata dengan keluarga ayahnya. 
tersebut harus dibuktikan dengan akta perkawinan, sedangkan akta perkawinan ini diperoleh setelah dilakukan pencatatan perkawinan.

Memperhatikan ketentuan yang terdapat dalam UU Perkawinan, maka UU ini sendiri tidak ada melarang perkawinan antar agama, tetapi tidak mengaturnya, sedangkan keabsahan perkawinan diserahkan kepada hukum agama masing-masing pihak. UU Perkawinan sebagai upaya unifikasi hukum perkawinan di Indonesia, tetapi substansinya sendiri masih bersifat pluralistik, karena didasarkan pada hukum agama. Sebagian agama di Indonesia melarang umatnya melakukan perkawinan antar agama, maka perkawinan antar agama hampir tidak mungkin disahkan oleh hukum Indonesia, tetapi ada beberapa agama yang mengizinkan umatnya melakukan perkawinan antar agama dengan dispensasi atau izin tertentu. Oleh sebab itu, jika agama membolehkan, maka pencatatan perkawinan di lembaga pencatat perkawinan semestinya dapat dilakukan setelah hukum agama mengesahkan perkawinan.

Setiap peristiwa kependudukan dan peristiwa penting yang dialami oleh penduduk yang berada di dalam atau di luar wilayah Indonesia wajib dicatatkan, dan hal ini bertujuan untuk memberikan perlindungan dan pengakuan status pribadi dan status hukum seseorang. Salah satu peristiwa penting yang menentukan status hukum seseorang adalah perkawinan, maka pencatatan perkawinan termasuk hak sipil warga negara yang harus dijamin pemenuhannya oleh negara. Persoalan pencatatan perkawinan yang berhubungan dengan akibat hukum dalam hukum nasional merupakan persoalan yang belum tuntas sampai sekarang dan perdebatan yang ada terkait dengan tentang sah atau tidaknya perkawinan yang tidak dicatatkan. Demikian juga dalam hubungannya dengan kesulitan untuk memproses perkara cerai di pengadilan bagi perkawinan yang tidak dicatatkan, serta akibat hukum yang terkait dengan hak atas nafkah, hak asuh anak, hak waris, dan lain-lain.

Dalam perspektif administrasi kependudukan, pendaftaran penduduk dan pencatatan sipil merupakan kegiatan yang sangat penting, karena dari kegiatan tersebut akan diperoleh data mikro yang aktual, dan tidak semata-mata agregatif. Oleh sebab itu, pendaftaran penduduk dan pencatatan sipil yang tertib dan valid berguna bagi pemerintah pusat dan pemerintah daerah untuk perencanaan program-program pembangunan sebagai dasar peningkatan dan pengembangan kualitas penduduk sendiri. ${ }^{11}$ Seperti yang dikatakan Darwin bahwa, masalah kependudukan merupakan salah satu titik sentral dalam pembangunan. Oleh karena itu, jika pemerintah ingin menyejahterakan rakyat, hal ini jangan pernah diabaikan, dan jika persoalan ini tidak diperhatikan dari daftar kebijakan pemerintah, Indonesia semakin terancam menjadi negara yang gagal. ${ }^{12}$

11 Sri Hendrastuti, Laporan Akhir Tim Penyusunan Naskah Akademis RUU Administrasi Kependudukan (Departemen Kehakiman dan Hak Asasi Manusia-BPHN 2004) 9.

12 Muhajir Darwin, 'Abaikan Kependudukan, Negara Terancam Gagal' (Kompas, 24 Maret 2007) dalam Lis Febrianda, 'Rekonstruksi Regulasi Pelayanan Kependudukan dan Pencatatan Sipil oleh Birokrasi Pemerintahan dalam Perspektif Hukum Administrasi Negara (Disertasi, Universitas Diponegoro 2009) 11. 
Tjiptoherijanto mengatakan bahwa masalah kependudukan merupakan isu yang sangat strategis dalam kerangka pembangunan nasional, karena: 13

1. Kependudukan atau dalam hal ini adalah penduduk, merupakan pusat dari seluruh kebijakan dan program pembangunan yang dilakukan. Penduduk adalah subjek dan objek pembangunan. Sebagai subjek pembangunan maka penduduk harus dibina dan dikembangkan sehingga mampu menjadi penggerak pembangunan. Sebaliknya pembangunan juga harus dapat dinikmati oleh penduduk yang bersangkutan, dengan demikian jelas bahwa pembangunan harus dikembangkan dengan memperhitungkan kemampuan penduduk agar seluruh penduduk dapat berpartisipasi aktif dalam dinamika pembangunan. Sebaliknya, pembangunan baru dikatakan berhasil jika mampu meningkatkan kesejahteraan penduduk dalam arti yang lebih luas lagi.

2. Keadaan atau kondisi kependudukan yang ada sangat mempengaruhi dinamika pembangunan yang dilakukan oleh pemerintah. Jumlah penduduk yang besar jika diikuti dengan kualitas penduduk yang memadai akan merupakan pendorong bagi pertumbuhan ekonomi. Sebaliknya jumlah penduduk yang besar jika diikuti dengan tingkat kualitas yang rendah, akan menjadikan penduduk tersebut sebagai beban bagi pembangunan.

3. Dampak perubahan dinamika kependudukan baru akan terasa dalam jangka waktu yang panjang, oleh sebab itu persoalan kependudukan dan pembangunan nasional harus ditangani secara cermat, sungguh-sungguh dan hati-hati. Kesalahan dalam penanganan akan berdampak buruk pada generasi mendatang dan bukan mustahil akan berdampak pada kehancuran bangsa.

Sejak berlakunya UU Adminduk, maka dapat dimaklumi bahwa pencatan sipil pada hakikatnya adalah untuk memberikan pemenuhan hakhak administratif, seperti pelayanan publik dan perlindungan yang berkenaan dengan dokumen kependudukan tanpa adanya perlakuan yang diskriminatif, yang juga bertujuan untuk: ${ }^{14}$

1. Memberikan keabsahan identitas dan kepastian hukum atas dokumen penduduk untuk setiap peristiwa kependudukan dan peristiwa penting yang dialami oleh penduduk;

2. Memberikan perlindungan status hak sipil penduduk;

3. Menyediakan data dan informasi kependudukan secara nasional mengenai pendaftaran penduduk dan pencatatan sipil pada berbagai tingkatan secara akurat, lengkap, mutakhir, dan mudah diakses sehingga menjadi acuan bagi perumusan kebijakan dan pembangunan pada umumnya;dan

4. Mewujudkan tertib administrasi kependudukan secara nasional dan terpadu.

5. Menyediakan data penduduk yang menjadi rujukan dasar bagi sektor terkait dalam penyelenggaraan se-

13 Prijono Tjiptoherijanto, Kependudukan Birokrasi dan Reformasi Ekonomi; Pemikiran dan Gagasan Masa Depan Pembangunan (Rineka Cipta 2004) 23-24.

14 Lihat Penjelasan Umum UU No. 23 Tahun 2006 tentang Adminduk. 
tiap kegiatan pemerintahan, pembangunan, dan kemasyarakatan.

Pencatatan perkawinan bukan syarat keabsahan perkawinan, ${ }^{15}$ melainkan hanya merupakan tindakan administratif yang penting untuk dilaksanakan. Pencatatan perkawinan memberikan bukti otentik terhadap status hukum seseorang melalui penerbitkan buku nikah atau akta perkawinan. Buku nikah atau akta perkawinan ini menjadi bukti bahwa perkawinan telah sah dan benar-benar terjadi dan oleh sebab itu setiap perkawinan harus dapat dicatatkan, tetapi agar suatu perkawinan dicatatkan, maka menurut UU Perkawinan disyaratkan adanya pemenuhan syarat berdasarkan agama terlebih dahulu.

Pencatatan dilakukan dengan menerbitkan sebuah akta perkawinan (buku nikah) dan akta tersebut mempunyai kekuatan hukum sebagai pembuktian sahnya perkawinan menurut hukum negara. Oleh sebab itu, status anak yang dilahirkan dari perkawinan yang sudah dicatatkan adalah sebagai anak yang memiliki hubungan hukum dengan kedua orang tuanya, ${ }^{16}$ dengan demikian, hak yang muncul bagi suami istri maupun anak-anak yang dilahirkan memiliki status yang jelas. ${ }^{17}$ Melalui pencatatan perkawinan, maka peristiwa perkawinan menjadi jelas dan terang, serta memenuhi syarat perkawinan sebagai- mana diatur dalam UU Perkawinan, dan perkawinan dibuktikan dengan keluarnya akta perkawinan, sehingga menimbulkan akibat hukum, baik bagi suami istri, keturunan dan masyarakat sekitar, serta bagi semua pihak yang berkepentingan.

Berdasarkan uraian di atas, maka dapat dikatakan bahwa pencatatan perkawinan mempunyai dua fungsi penting, yaitu fungsi administratif dan fungsi normatif. Fungsi administratif dimaksudkan untuk mendapatkan data akurat dan valid bagi kepentingan perencanaan pembangunan negara dalam seluruh aspek kehidupan, oleh sebab itu merupakan kewajiban bagi setiap orang yang telah melangsungkan perkawinan untuk mencatatkan perkawinannya. ${ }^{18}$ Fungsi normatif dimaksudkan untuk memberikan jaminan kepastian hukum terhadap perkawinan yang telah dilangsungkan, karena dengan tercatatnya perkawinan, maka dapat dibuktikan bahwa perkawinan memang benar telah dilangsungkan, sehingga hak-hak para pihak dalam perkawinan yang timbul dalam lapangan hukum keluarga wajib dipenuhi dan oleh sebab itu pula timbul kewajiban negara untuk mencatatkan perkawinan yang telah dilangsungkan sebagai bagian kewajiban dan tanggung jawab negara untuk melindungi setiap warga negaranya. ${ }^{19}$

15 Tengku Erwinsyahbana, 'Perspektif Hukum Perkawinan Antar Agama yang Berkeadilan Dikaitkan dengan Politik Hukum Perkawinan Indonesia dalam Rangka Pembangunan Hukum Keluarga Nasional' (2012) 2 Indonesian Journal of Dialectics 72, 82.

16 Sulistyowati Sugondo, Pokok-pokok Pikiran dan Paradigma Baru Catatan Sipil Nasional (Komnas HAM 2005) 8.

17 Ibid.

18 Pasal 3 UU No. 23 Tahun 2006 tentang Adminduk menentukan bahwa: "setiap penduduk wajib melaporkan peristiwa kependudukan dan peristiwa penting yang dialaminya kepada instansi pelaksana dengan memenuhi persyaratan yang diperlukan dalam pendaftaran penduduk dan pencatatan sipil".

19 Pasal 5 UU No. 23 Tahun 2006 tentang Adminduk menentukan bahwa: "Pemerintah berkewajiban dan bertanggung jawab menyelenggarakan Administrasi Kependudukan secara nasional ..." 
Pencatatan perkawinan merupakan kewajiban yang harus dilaksanakan oleh seseorang yang telah melangsungkan perkawinan, karena berdasarkan Pasal 3 UU Adminduk, ditegaskan bahwa setiap penduduk wajib melaporkan peristiwa kependudukan dan peristiwa penting yang dialaminya kepada Instansi Pelaksana dengan memenuhi persyaratan yang diperlukan dalam Pendaftaran Penduduk dan Pencatatan Sipil, dan selanjutnya berdasarkan Pasal 2 Perpres No. 25 Tahun 2008 tentang Persyaratan dan Tata Cara Pendaftaran Penduduk dan Pencatatan Sipil (Perpres No. 25 Tahun 2008), ditegaskan bahwa pendaftaran penduduk dan pencatatan sipil bertujuan untuk memberikan keabsahan identitas dan kepastian hukum atas dokumen penduduk, perlindungan status hak sipil penduduk, dan mendapatkan data yang mutakhir, benar dan lengkap.

Perkawinan dan pencatatan perkawinan merupakan 2 (dua) peristiwa yang berbeda, sehingga masalah keabsahan perkawinan tidak tergantung kepada persoalan pencatatan perkawinan. Sahnya perkawinan apabila perkawinan tersebut dilaksanakan menurut agama atau kepercayaan, dengan demikian jika menurut agama suatu perkawinan sah, maka perkawinan tersebut adalah sah. Terkait dengan pencatatan perkawinan yang merupakan kewajiban untuk dilaksanakan, tidak menjadi ukuran sah atau tidak sahnya perkawinan, karena berdasarkan Pasal 2 Perpres No. 25 Tahun 2008, pencatatan sipil hanya bertujuan untuk memberikan "keabsahan identitas" dan "kepastian hukum atas dokumen penduduk", "perlindungan status hak sipil penduduk", dan "mendapatkan data yang mutahir, benar dan lengkap", jadi bukan untuk menjadi ukuran atau alasan sahnya perkawinan.

Penulis cenderung berpendapat bahwa pencatatan perkawinan tidak merupakan syarat sah suatu perkawinan, karena syarat sah perkawinan adalah sesuai syarat atau ketentuan yang terdapat dalam ajaran (kaedah) agama, tetapi pencatatan perkawinan mutlak harus dilaksanakan demi melindungi hak-hak para pihak dalam satu keluarga, yang terdiri dari suami, isteri dan anak/ anak-anak yang dilahirkan dari perkawinan itu. Melalui pencatatan perkawinan yang diikuti dengan terbitnya Buku Nikah, akan dapat membuktikan bahwa seseorang memang benar sedang terikat dalam satu ikatan perkawinan, sehingga para pihak dapat menuntut hak-haknya dan dituntut untuk memenuhi kewajibannya yang tertuang dalam UU No. 1 Tahun 1974. Dengan demikian, pencatatan perkawinan dilakukan tidak bertujuan untuk membuktikan sahnya perkawinan dalam pengertian sah menurut agama, tetapi sematamata hanya sebagai pengakuan (legalisasi) dari negara bahwa para pihak dalam perkawinan memang benar terikat dalam suatu ikatan perkawinan, dengan kata lain untuk membuktikan identitas diri seseorang bahwa dirinya adalah benar suami atau isteri dari seseorang, serta untuk membuktikan status seorang anak sebagai anak dari pasangan suami isteri.

\section{PENUTUP}

Sebelum berlakunya UU Perkawinan, KCS diberi kewenangan untuk melangsungkan dan mencatat perka- 
winan. Hal ini ditegaskan dalam Pasal 81 dan Pasal 100 KUHPerdata. Setelah berlakunya UU Perkawinan, perkawinan antar agama menjadi suatu permasalahan tersendiri, sehingga KCS tidak lagi berwenang mencatatkan perkawinan pasangan suami istri yang berbeda agama.

Perkawinan dengan pencatatan perkawinan merupakan 2 (dua) peristiwa yang berbeda, sehingga masalah keabsahan perkawinan tidak tergantung kepada persoalan pencatatan perkawinan. Sahnya perkawinan apabila perkawinan tersebut dilaksanakan menurut agama atau kepercayaan, dengan demikian jika menurut agama suatu perkawinan adalah sah, maka perkawinan tersebut sah secara yuridis. Pencatatan perkawinan yang merupakan kewajiban untuk dilaksanakan, tidak menjadi ukuran sah atau tidak sahnya perkawinan, karena pencatatan sipil hanya bertujuan untuk memberikan "keabsahan identitas" dan "kepastian hukum atas dokumen penduduk", "perlindungan status hak sipil penduduk", dan "mendapatkan data yang mutahir, benar dan lengkap", jadi tidak untuk menjadi ukuran atau alasan sahnya perkawinan.

Setiap penduduk hendaknya melaporkan peristiwa kependudukan dan peristiwa penting yang dialaminya (termasuk pula peristiwa perkawinan), karena pendaftaran penduduk dan pencatatan sipil bertujuan untuk memberikan keabsahan identitas dan kepastian hukum atas dokumen penduduk, perlindungan status hak sipil penduduk, dan mendapatkan data yang mutakhir, benar dan lengkap.

Pasal 2 ayat (1) UU Perkawinan yang terkait dengan ketentuan sahnya perkawinan dan Pasal 2 ayat (2) UU
Perkawinan yang terkait dengan ketentuan pencatatan perkawinan hendaknya diletakkan secara terpisah dalam pasal yang berbeda, sehingga pencatatan perkawinan tidak lagi dimaksudkan sebagai syarat sah perkawinan, melainkan hanya sebagai syarat yang terkait dengan bidang administrasi kependudukan.

\section{DAFTAR BACAAN}

\section{Buku}

Hartono, S., Politik Hukum Menuju Satu Sistem Hukum Nasional (Alumni 1991).

Hendrastuti, S., Laporan Akhir Tim Penyusunan Naskah Akademis RUU Administrasi Kependudukan (Departemen Kehaki-man dan Hak Asasi Manusia-BPHN 2004).

Ibrahim, J., Teori dan Metodologi Penelitian Hukum Normatif (Bayumedia Publishing 2006).

Mulia, Siti M., (dkk), 'Beda Agama: Kesaksian, Argumen Keagamaan dan Analisis Kebi-jakan' dalam Ahmad Nurcholish dan Ahmad Baso (ed) (Komnas HAM-ICRP 2010).

Soekanto, S., dan Mamudji, S., Penelitian Hukum Normatif Suatu Tinjauan Singkat (Raja Grafindo Persada 2003).

Sugondo, S., Pokok-pokok Pikiran dan Paradigma Baru Catatan Sipil Nasional (Komnas HAM 2005).

Sunggono, B., Metodologi Penelitian Hukum (RajaGrafindo Persada 1998).

Tjiptoherijanto, P., Kependudukan Birokrasi dan Reformasi Ekonomi; Pemikiran dan Gagasan Masa 
Depan Pembangunan (Rineka Cipta 2004).

\section{Artikel Jurnal}

Alesyanti, Tengku E., and Fatimah Sari Siregar, 'Design of Sex Educational Material in Children as Early Anticipation of Pedophilia in Medan City and its Dissemination through Information and Communication Technology' (2018) 1114 Journal of Physics: Conference Series 1.

Ceprudin, 'Perlindungan Hukum terhadap Perkawinan Penganut Sedulur Sikep di Kabupaten Kudus' (2016) 1 Refleksi Hukum: Jurnal Ilmu Hukum.

Erwinsyahbana, T., dan Harmita, 'Kekuatan Hukum Surat Keterangan Ahli Waris bagi Anak Luar Kawin dari Perkawinan Tidak Tercatat' (2017) 8 Jurnal Hukum Novelty.

Erwinsyahbana, T., 'Pertanggungjawaban Yuridis Direksi Terhadap Risiko Kerugian Keuangan Daerah pada Badan Usaha Milik Daerah' (2017) 2 Jurnal De Lega Lata.

Erwinsyahbana, T.,, 'Perspektif Hukum Perkawinan Antar Agama yang Berkeadilan Dikaitkan dengan Politik Hukum Perkawinan Indonesia dalam Rangka Pembangunan Hukum Keluarga Nasional' (2012) 2 Indonesian Journal of Dialectics.

Usman, R., 'Makna Pencatatan Perkawinan dalam Peraturan Perundang-Undangan Perkawinan di Indonesia' (2017) 14 Jurnal Legislasi Indonesia.

\section{Disertasi}

Febrianda, L., 'Rekonstruksi Regulasi Pelayanan Kependudukan dan Pencatatan Sipil oleh Birokrasi Pemerintahan dalam Perspektif Hukum Administrasi Negara (Disertasi, Universitas Diponegoro 2009).

\section{Peraturan Perundang-Undangan}

Undang-Undang Nomor 1 Tahun 1974 tentang Perkawinan.

Undang-Undang Nomor 23 Tahun 2006 tentang Administrasi Kependudukan.

Undang-Undang Nomor 24 Tahun 2013 tentang Perubahan Atas Undang-Undang Nomor 23 Tahun 2006 tentang Administrasi Kependudukan.

Peraturan Pemerintah Nomor 9 Tahun 1975 tentang Pelaksanaan Undang-Undang Nomor 1 Tahun 1974 tentang Perkawinan.

Keputusan Presiden Nomor 12 Tahun 1983 tentang Penataan dan Peningkatan Pembinaan dan Penyelenggaraan Catatan Sipil.

Peraturan Presiden Nomor 25 Tahun 2008 tentang Persyaratan dan Tata Cara Pendaftaran Penduduk dan Pencatatan Sipil. 
